\title{
Studies on the dispersal of staphylococci
}

\author{
W. C. NOBLE AND R. R. DAVIES \\ With the technical assistance of DOREEN A. PLACE \\ From the Wright-Fleming Institute of Microbiology, \\ St. Mary's Hospital Medical School, London
}

SYNOPSIS The dispersal of staphylococci during undressing in a cubicle has been investigated ${ }^{\omega}$ The ability to disperse appears to be largely dependent on the degree of contamination of the skiff with staphylococci. There are some major differences in the numbers of bacteria and skin scaleso disseminated by different groups of people, e.g., patients with skin disease disseminated more thandid normal persons. Differences in dissemination between males and females appeared to be largely $\vec{\sigma}$ due to differences in clothing.

During studies on cross-infection in hospital wards, 'broadcasts' of staphylococci were observed (Shooter, Smith, Griffiths, Brown, Williams, Rippon, and Jevons, 1958) which were later thought to be caused by the activity of individual patients, referred to as 'dispersers' (Noble, 1962). Hare and his colleagues (Hare and Thomas, 1956; Hare and Ridley, 1958) showed that some persons possessed the ability to disseminate staphylococci into their environment and that this ability appeared to be related to perineal carriage of the staphylococci.

Airborne staphylococci have been found to be associated with particles of a median equivalent diameter of about $13 \mu$ (Lidwell, Noble, and Dolphin, 1959) but the mean number of live cocci in these airborne particles appeared to be of the order of onlyfour cocci. The staphylococci seemed to becarried on a raft of some description and Davies and Noble $(1962,1963)$ showed that these rafts were fragments of desquamated human skin.

It therefore seemed worth investigating whether the 'dispersers' observed in the wards shed more skin particles than normal persons, or whether their carriage of staphylococcci was different.

\section{METHODS}

A cubicle similar to that described by Hare and Thomas (1956) was constructed of plastic curtain material. It was $4 \mathrm{ft} . \times 4 \mathrm{ft} . \times 7 \frac{1}{2} \mathrm{ft}$. high $(116 \mathrm{cu}$. ft. $)$ and contained two slit samplers sampling at one and 10 cubic feet per minute (28.3 and 283 litres/min.), a portable spore trap (Gregory, 1954) which samples air at a rate of $0.35 \mathrm{cu}$. $\mathrm{ft} . / \mathrm{min}$. (10 litres/min.) through a slit, the airborne particles being impacted onto a stationary microscope slide coated with a thin layer of petroleum jelly (Gregory, 1954), and,

Received for publication 8 April 1964. in some experiments a size-grading slit sampler (Lidwell 1959). The sampling orifices were $4.5 \mathrm{ft}$. $(1.4 \mathrm{~m}$.) fronf the floor; suction pumps for all but the size-grading sampler were outside the cubicle. The cubicle stood in ao small room which could be ventilated by means of an extraction fan in the window and was not used for anypurpose other than the experiment.

The test for dispersal consisted of collecting airborne bacteria and skin scales during a two-minute period irp which the subject undressed, an activity known to release large numbers of bacteria (Duguid and Wallace, 1948) Persons using the cubicle were instructed to start the samplers by pressing a switch and to undress completely while the samplers were running. The samplers were, switched off automatically. The bacterial flora of the nose and of the skin of the chest, forearm, shin, and perineum was determined using broth-moistened swabs $\bar{\Omega}$ An attempt was made to assess quantitatively the skin flora over the scapula, tibia, and abdomen of 35 persons 3 using Sellotape (Thomas, 1961) but the results proved difficult to interpret owing to the wide variations in bacterial counts at different sites on any one person? Serial stripping of the skin showed, however, that in most subjects the bacteria were not found deep in thes skin, although in a few individuals bacteria appeared to be as deep as the conjunctum.

All cultures and air samples were made on serum aga plates containing phenolphthalein phosphate (Barber and Kuper, 1951) as an indicator medium for staphylococci The word staphylococcus used without qualification w implies the coagulase-positive Staphylococcus aureus.

Sticky slides for the spore trap were made by coating microscope slides with petroleum jelly. Deposits of impacted dust were stained with carbol fuschin tơ facilitate the recognition of desquamated skin scales and the numbers in $1 / 16$ of the area of the deposit counted 6 (corresponding to a sample of $0.04 \mathrm{cu}$. $\mathrm{ft}$.).

Control samples were taken before each person use the cubicle and the number of skin scales and bacteria in the samples was subtracted from the count observe 
while the person undressed. After use the cubicle was ventilated for at least one hour before a new person was admitted.

\section{PERSONS STUDIED}

NORMAL PERSONS These were laboratory staff and students having no known skin disease and no staphylococcal disease.

HOSPITAL IN-PATIENTS These were patients from medical and surgical wards, 10 of whom were suspected of being dispersers. None of these patients had any known skin disease and some were examined by a dermatologist to exclude the possibility of any skin abnormalities. In contrast to the normal persons and the patients with skin diseases, the hospital in-patients came into the cubicle in pyjamas and dressing-gown in place of normal street clothing.

PATIENTS WITH SKIN DISEASES These patients were usually attending the out-patient clinics and have here been divided into four groups:

A Patients less than 7 years of age with eczema; many were less than 18 months old and had to be undressed by their mothers.

B Patients over 7 years of age with eczema.

C Adult patients with seborrhoeic dermatitis, exfoliative dermatitis, mycosis fungoides etc., but not eczema.

D Adult patients with staphylococcal skin disease such as boils, carbuncles etc.

Patients with skin diseases were included in the survey because it has been reported that they present a greater risk of spreading cross-infection than other patients (e.g., Hare and Cooke, 1961).

Dispersal has been defined as the occurrence of staphylococci as more than $1 \%$ of the airborne flora disseminated while the person undressed. According to this definition, a total of 30 'dispersers' was found amongst 127 people. The level of $1 \%$ of the total flora was equivalent to 0.25 particles per cubic foot (or 25 particles in the whole volume of the cubicle) in all cases. This concentration of staphylococci was greatly exceeded by many of the dispersers, however (Table I). It is difficult to make exact comparisons between these dispersers and those observed previously in the wards (Noble, 1962)
TABLE I

QUANTITATIVE DISPERSAL OF STAPHYLOCOCCI

Concentration of Staphylococci per cu. ft. in Total Air of the Cubicle when Disperser Undressed

\begin{tabular}{lllllll}
\hline 0.25 & 0.5 & 1 & 5 & 10 & 20 & 100
\end{tabular}

No. of

$\begin{array}{lllllllll}\text { 'dispersers'1 }^{2} & 1^{2} & 2 & 5 & 3 & 4 & 7 & 8 & 30\end{array}$

${ }^{1}$ Dispersers defined on the basis that Staphylococcus aureus formed at least $1 \%$ of the total airborne flora.

${ }^{2}$ One other normal person, a nose and skin carrier, gave a level of 0.25 staphylococci/cu. ft. but this did not total more than $1 \%$ of the airborne flora.

but at least 22 of the 30 gave a level of air contamination well within the levels observed in the wards.

Carriage of staphylococci at a particular site was defined as the isolation of six or more colonies of Staphylococcus aureus on the agar plate on which the swab was inoculated.

\section{RESULTS}

DISPERSAL OF STAPHYLOCOCCUS AUREUS All but three of the subjects who were dispersers were skin carriers of staphylococci and of the three who were not known to be skin carriers, two had staphylococcal skin disease in the form of carbuncles (Table II). Twenty-one of the 29 adult skin carriers dispersed staphylococci as more than $1 \%$ of the airborne flora. Table III shows that the skin carriers who were not dispersers were, in general, those with only one skin site colonized with staphylococci. It is interesting in view of the work of Hare and his colleagues (Hare and Thomas, 1956; Hare and Ridley, 1958; Hare and Cooke, 1961) to observe that, whilst all of those who were perineal carriers of staphylococci were dispersers, some of the dispersers were not perineal carriers.

DISSEMINATION OF BACTERIA AND SKIN SCALES Dispersers of staphylococci who had no known skin disease did not shed a significantly greater total of bacteria or skin scales than did the non-dispersers. It was found, however (Table IV), that patients with

\section{TABLE II}

DISPERSAL OF STAPHYLOCOCCI IN RELATION TO CARRIAGE

\begin{tabular}{|c|c|c|c|c|c|c|c|c|}
\hline \multirow[t]{2}{*}{ Group $^{1}$} & \multicolumn{2}{|c|}{ Non-carriers } & \multicolumn{2}{|c|}{ Nasal Carriers Only } & \multicolumn{2}{|c|}{ Nose and Skin Carriers } & \multicolumn{2}{|c|}{ Skin Carriers Only } \\
\hline & Total & Dispersers & Total & Dispersers & Total & Dispersers & Total & Dispersers \\
\hline Normal persons & 39 & 0 & 8 & 0 & 5 & 2 & 2 & 0 \\
\hline $\begin{array}{l}\text { Hospital in-patients } \\
\text { Patients with skin diseases }\end{array}$ & 22 & $\mathbf{0}$ & 4 & $\mathbf{0}$ & 6 & 6 & $\mathbf{0}$ & $\mathbf{0}$ \\
\hline A Infant eczema & 1 & 0 & 0 & 0 & 7 & 6 & $\mathbf{0}$ & 0 \\
\hline B Adult eczema & 0 & 0 & 1 & 0 & 9 & 7 & $\mathbf{0}$ & $\mathbf{0}$ \\
\hline C Skin disease & 6 & 0 & 4 & 1 & 5 & 5 & 1 & 0 \\
\hline D Staphylococcal skin disease & 1 & 0 & 5 & 2 & 1 & 1 & 0 & $\mathbf{0}$ \\
\hline Total & 69 & 0 & 22 & 3 & 33 & 27 & 3 & 0 \\
\hline
\end{tabular}


TABLE III

DISTRIBUTIONS OF CARRIAGE SITES ${ }^{1}$

\begin{tabular}{|c|c|c|c|c|c|c|}
\hline \multicolumn{5}{|c|}{ Carriage Site } & \multirow{2}{*}{$\begin{array}{l}\text { Total } \\
\text { Persons }\end{array}$} & \multirow{2}{*}{$\begin{array}{l}\text { Number of } \\
\text { Dispersers }\end{array}$} \\
\hline Nose & Wrist & Shin & Chest & Perineum & & \\
\hline+ & + & + & + & + & 7 & 7 \\
\hline+ & + & + & + & - & 2 & 2 \\
\hline+ & + & - & + & + & 1 & 1 \\
\hline+ & + & + & - & - & 4 & 4 \\
\hline+ & - & - & + & + & 1 & 1 \\
\hline+ & - & - & - & + & 1 & 1 \\
\hline+ & - & - & + & - & 6 & 4 \\
\hline+ & + & - & - & - & 3 & 1 \\
\hline+ & - & + & - & - & 1 & 0 \\
\hline- & + & - & - & - & 3 & 0 \\
\hline
\end{tabular}

'Eczema patients less than 7 years of age have been omitted from this table.

skin diseases disseminated more skin scales and more bacteria of all varieties than either the normal persons or the hospital in-patients, and that males disseminated more than females. There were no significant differences between the normal males and the male hospital in-patients or the normal females and the female in-patients. The distribution of skin scales is shown in the Figure.

\section{TABLE IV}

MEAN NUMBER OF SKIN SCALES AND BACTERIA DISSEMINATED DURING UNDRESSING

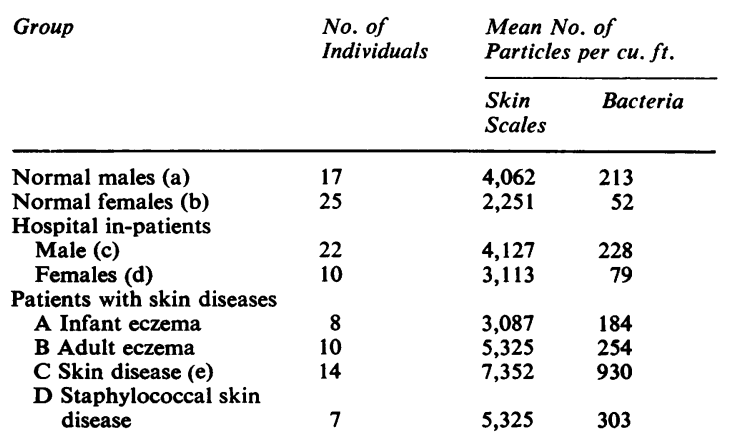

Each person appears only once in this table.

Statistical analysis revealed the following relations between the groups:

Skin scales Groups a and c no significant difference $(P>10 \%)$ $b$ and $d$ no significant difference $(P>10 \%)$ a and e difference significant $(5 \%>\mathbf{P}>2 \%)$ $a$ and $b$ difference significant $(P<0.1 \%)$

Bacteria Groups a and c no significant difference $(P>10 \%)$ $b$ and $d$ no significant difference $(P>10 \%)$ a and e no significant difference ( $P>10 \%)$ $a$ and $b$ difference significant $(P<0.1 \%)$

There was a strong correlation between the number of skin scales and the total number of bacteria disseminated into the air $(P<1 \%)$.

SIZE DISTRIBUTION OF PARTICLES There is a suggestion that particles carrying microorganisms disseminated by patients with skin diseases were smaller than those disseminated by normal persons (Table V).

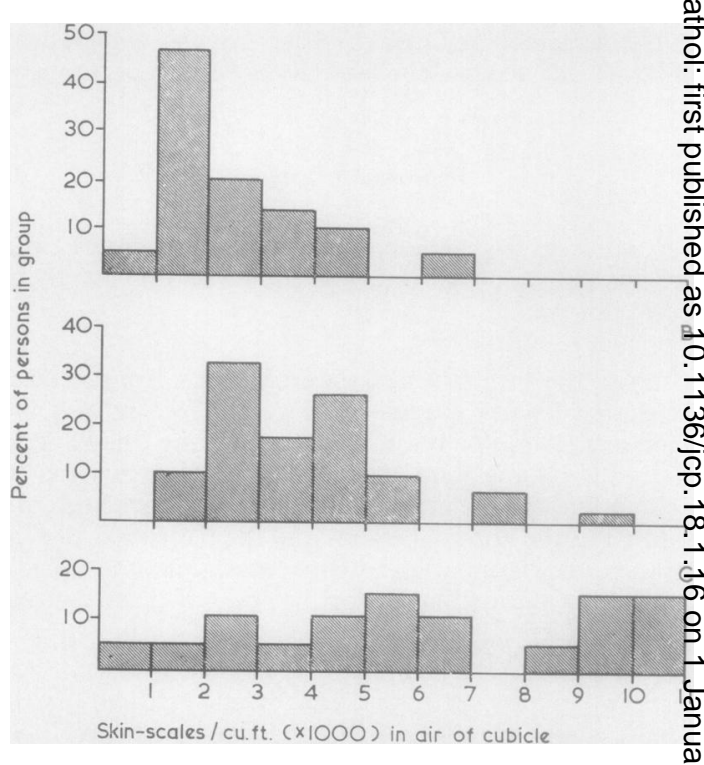

FIG. 1. Distribution of skin scale counts among variots groups investigated.

However, this takes into account only those particles which remain airborne for long enough te be sampled; it does not include the very large particles shed by patients with, for example exfoliative dermatitis. The size distribution nevertheless very similar to that observed in the open wards (Noble, Lidwell, and Kingston, 1963) the slight excess of larger particles is probably due t $\theta$ the fact that the samples were taken in a cubicle an there was, therefore, a tendency to sample large particles than would otherwise be the case.

\section{TABLE V}

SIZE DISTRIBUTION OF AIRBORNE PARTICLES CARRYING BACTERIA

\begin{tabular}{|c|c|c|c|c|c|c|c|}
\hline \multirow[b]{2}{*}{ Group } & \multicolumn{7}{|c|}{ Median-equivalent Diameter $(\mu)$} \\
\hline & $10-12$ & $12-14$ & $14-16$ & $16-18$ & $18-20$ & $20-22$ & Total \\
\hline $\begin{array}{l}\text { Normal persons } \\
\text { Patients with skin }\end{array}$ & 0 & 5 & 6 & 10 & 4 & 4 & 29 \\
\hline diseases & 3 & 7 & 5 & 1 & 1 & 0 & 17 \\
\hline
\end{tabular}

FURTHER INVESTIGATION OF NORMAL PEOPLE There were considerable differences between the number of skin scales and bacteria disseminated by males an by females. This could be due either to differencess in the skin of males and females or to differences in clothing, since all the normal persons entered the cubicle in ordinary clothing.

To try to distinguish between the various factors a number of the normal persons were investigated on more than one occasion; it was found that there 
was considerable variation in the counts both of skin scales and bacteria disseminated by the same person on different occasions, such that these differences were as large as those between different persons of the same sex.

In general the men in the survey tended to be of bigger build than the women but the differences in dissemination either between or within the sexes could not be explained on the basis of surface area. Allowances for differences in surface area (by covariance analysis) did not eliminate the differences between males and females in the number of particles dispersed.

To determine whether differences in clothing might be responsible for differences in the number of bacteria and skin scales shed, a number of normal persons changed into laundered, sterile cotton pyjamas in a room remote from the cubicle. After wearing the pyjamas for 10 minutes these people entered the cubicle and undressed as before (Table VI).

\section{TABLE VI}

EFFECT ON DISSEMINATION OF CHANGING INTO COTTON PYJAMAS

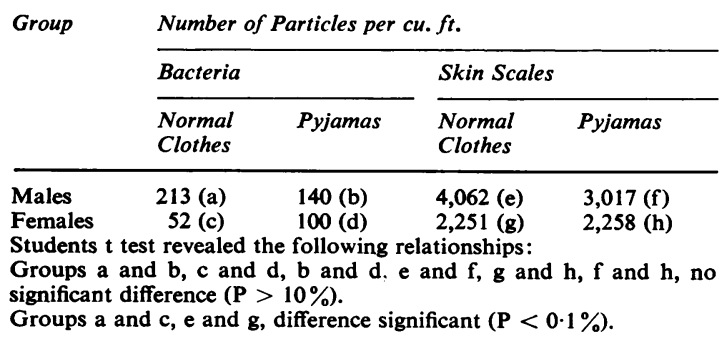

When undressing from pyjamas, males disseminated fewer particles and females more particles bearing microorganisms than from normal clothes so that the former significant differences between the sexes had disappeared. Thus a major part of the differences between males and females in the number of bacteria and skin scales disseminated during undressing could be accounted for on the basis of differences in clothing.

\section{DISCUSSION}

It must be emphasized that 10 of the hospital inpatients in this series were selected because epidemiological studies in the wards had suggested that they might be dispersers; their bedclothes were heavily contaminated with staphylococci. Six of them proved to be dispersers and it is of interest that all of them were infected with the same staphylococcus, presumably acquired in the wards, although this is certain for only three of the patients. The series was further weighted in favour of dispersers by the inclusion of patients with skin diseases who appear to be particularly susceptible to colonization with staphylococci. Phage typing revealed that each of the patients with skin disease carried a different staphylococcus.

Differences in the quantities of skin scales and bacteria disseminated by normal persons appeared to be largely dependent on the nature of the clothing although the effect of clothing on dissemination was less marked amongst the females than amongst males. No relation of degree of dissemination to surface area was found but since this varied only from 1.5 square metres to 2 square metres, any difference that existed may have been swamped by the inherent variation. It is recognized that 'undressing' is a far from standard technique, but the use of several individuals in each group and statistical analysis of results should have helped to eliminate some of the variability.

It seems probable that the most important feature of a disperser is that the skin is colonized by staphylococci. It was found that one patient (a farm hand) who yielded a Bacillus species from the chest swab also disseminated this organism into the air. Clayton and Noble (1963) showed that fungi causing skin disease may be disseminated during examination in clinics. In the absence of any precise method for identifying the coagulase-negative flora of the skin, no exact statement on the dispersal of other bacteria can be made, but it is our belief that all microorganisms on the skin may be disseminated in the manner described.

We are indebted to Dr. M. Feiwel and other members of the Skin Department and to the physicians and surgeons of St. Mary's Hospital for permission to see their patients; and to our colleagues who took part in this investigation.

\section{REFERENCES}

Barber, M., and Kuper, S. W. A. (1951). J. Path. Bact., 63, 65.

Clayton, Y. M., and Noble, W. C. (1963). Trans. St. John's Hosp. Derm. Soc. (Lond.), 49, 36.

Davies, R. R., and Noble, W. C. (1962). Lancet, 2, 1295.

- - (1963). Ibid., 1, 1111.

Duguid, J. P., and Wallace, A. T. (1948). Ibid., 2, 845.

Gregory, P. H. (1954). Trans. Brit. mycol. Soc., 37, 390.

Hare, R., and Cooke, E. M. (1961). Brit. med. J., 2, 333. , and Ridley, M. (1958). Ibid., 1, 69.

$\longrightarrow$, and Thomas, C. G. A. (1956). Ibid., 2, 840.

Lidwell, O. M. (1959). J. sci. Instrum., 36, 3.

-, Noble, W. C., and Dolphin, G. W. (1959). J. Hyg. (Lond.), 57, 299.

Noble, W. C. (1962). J. clin. Path., 15, 552.

, Lidwell, O. M., and Kingston, D. (1963). J. Hyg. (Lond.), 61, 385.

Shooter, R. A., Smith, M. A., Griffifths, J. D., Brown, M. E. A., Williams, R. E. O., Rippon, J. E., and Jevons, M. P. (1958). Brit. med. J., 1, 607.

Thomas, M. (1961). Mth. Bull. Minist. Hlth Lab. Serv., 20, 37. 